\title{
Manitoba Association of Health Information Providers
}

The Manitoba Association of Health Information Providers (MAHIP) held a number of activities to meet the interests and needs of its membership in the first few months of 2011.

\section{Programming}

On February 18, MAHIP hosted an update of the Canadian Virtual Health Library / Bibliothèque virtuelle canadienne de la santé (CVHL/BVCS) at the Neil John Maclean Library. Orvie Dingwall, Jennifer Bayne, and Judy Inglis were on hand to provide this overview of the CVHL/BVCS and answer questions. Many people came to hear about the status of the project which drew a lot of positive comments.

Journal Club continued to be a popular activity with one meeting held in March. All articles discussed at Journal Club are listed on the MAHIP website (http:// mahip.wordpress.com/journal-club/).

On May 5, MAHIP hosted "Virtual Realities Information Pathways in a Digital World." This one-day symposium focused on the role of virtual and mobile technologies in libraries and was open to all members of the library community. The keynote speakers were Leslie Beard and Dr. Jennifer Keelan of the Centre for Innovation in Complex Care in Toronto, Ont. Beard and Keelan spoke about their work in providing health information in virtual environments and, specifically, in second life. Laurie Blanchard and Jan Guise, University of Manitoba Libraries, presented a workshop on developmental evaluation. Dr. Patricia Martens, Faculty of Medicine, University of Manitoba, presented a second workshop on constructing online surveys. The day ended with a panel discussion "Connecting Clients with Information in a Virtual World" which was moderated by Sherri Vokey, University of Manitoba Libraries. In total, 21 people attended the symposium and evaluations were extremely positive. MAHIP applied for and was successful in receiving funding for this continuing education initiative through the CHLA Chapter Initiative Fund. Two people were awarded MAHIP Continuing Education Awards to attend this event.

\section{MAHIP chapter history project}

Christine Shaw-Daigle, Lisa Demczuk, Angela Osterreicher, and Melissa Raynard published an article in JCHLA [1] describing their work on the Manitoba History Project which they started to document the development and achievements of the Association since its inception in 1976.

\section{Annual general meeting}

The following new executive was elected at the AGM held on June 16, 2011: Lori Giles-Smith, President; Andrea Szwajcer, Vice President; Angela Osterreicher, Past President; Alison Pattern, Treasurer; and Kerry Macdonald, Secretary.

\section{Upcoming events}

As the new chapter year begins, there are already plans for an equally valuable program of events. To celebrate the 35th anniversary of MAHIP, plans are underway for a celebration dinner to be held in the fall. The MAHIP Journal Club is scheduled to meet four times between September and April. The Program Committee is considering how our association can contribute to the Manitoba Libraries Conference in Winnipeg next spring and is also planning a "movie" night.

\author{
Lori Giles-Smith \\ MAHIP President \\ Hospital Librarian, University of Manitoba Libraries \\ Bill Larson Library, Grace Hospital \\ 300 Booth Drive \\ Winnipeg, MB R3J 3M7, Canada \\ E-mail: lori_giles-smith@umanitoba.ca
}

\section{References}

1. Shaw-Daigle C, Demczuk L, Osterreicher A, Raynard M. A look back on the prairie: the Manitoba Health Library Association / Manitoba Association of Health Information Providers (MHLA / MAHIP) chapter history project. Journal of the Canadian Health Libraries Association, 2011;32(1): 17-9. doi:10.5596/c11-013. 